KATIE MAGNUS is a $3^{\text {rd }}$ year Political Science major concentrating in Global Politics. Throughout her time at Cal Poly she has been involved in Model United Nations, traveling to conferences throughout the U.S. with her fellow delegates. Katie has also worked at Cal Poly Phonathon since her freshman year. After a summer spent in New York City interning for the U.S. Mission to the United Nations, she is convinced that International Relations is the field for her, and that New York is the city for her. Originally hailing from Wisconsin, Katie is a dedicated Green Bay Packers fan. 


\section{POLICY IMPLICATIONS OF THE AUTHORIZATION FOR THE USE OF MILITARY FORCE: UNMANNED AERIAL VEHICLES?}

Katie Magnus

The Authorization for the Use of Military Force (AUMF) is a piece of legislation that was enacted shortly after the attacks on September 11, 2001. It states,

That the President is authorized to use all necessary and appropriate force against those nations, organizations, or persons he determines planned, authorized, committed, or aided the terrorist attacks that occurred on September 11, 2001, or harbored such organizations or persons, in order to prevent any future acts of international terrorism against the United States by such nations, organizations or persons. ${ }^{25}$

This almost sixty word sentiment laid the ambiguous foundation for the United States military policy in the post 9/11 era. Following the AUMF was the war in Afghanistan, the war in Iraq, as well as Special Forces operating in nations where the U.S. was not directly at war. More recently, during the end of the

25 S.J.Res. 23 (107th): Authorization for Use of Military Force. 107th Congress, 2001-2002. Text as of Sep 18, 2001 (Passed Congress/Enrolled Bill) https://www.govtrack.us/congress/bills/107/ sjres23/text 
Bush Administration and continuing throughout the Obama Administration, the U.S. utilized Unmanned Aerial Vehicles or drones to combat terrorists and/ or terrorist organizations within nations where the U.S. is not at war. Many of these policies have created new questions involving legality and the protection of an individual's rights. A main implication of the AUMF has been the increased use of UAVs or drones as a counterterrorism tool. The paper will explore this implication, the elevation of drone usage, and the repercussions it has for the United States and the international community as a whole.

\section{Literature Review}

Much of the academic literature on this topic can be organized into several different camps, a few of which this literature review will feature. The schools of thought can be divided into about three groups; one group of scholars highlight the necessity of drones as a tool for the U.S., but also focus on the fact that the program needs to improve in the future. Another band of academics look at some of the legal aspects of UAVs, primarily arguing that the legal foundation utilized by the Bush and Obama Administrations for drone strikes is flawed. The last school of thought that will be discussed is the grouping of articles that claim that UAVs are not useful at all, advocating against their usage. The United States' drone program is controversial, so there are many topics covered throughout academia. The pieces reviewed for this paper comprise the most general classifications.

There are some scholars who showcase concern over the future of the drone campaign instead of focusing on past missteps of the campaign. A Foreign Affairs article by Kreps and Zenko recommends specific changes to the current administration's policy, beginning with a reminder that the United States, as a world power, needs to lead by example. There will come a time when the global development of UAV technology will rival the technology of the United States. Nations looking to utilize drones for one reason or another will follow the precedents set by the U.S. Zenko and Kreps state, "Spurred by the United States' example, other countries are likely to threaten or conduct drone strikes in ways that are harmful to U.S. interests, whether by provoking regional adversaries or targeting domestic enemies." ${ }^{26}$ More specifically, the authors argue

${ }^{26}$ Kreps, Sarah, and Micah Zenko. "The Next Drone Wars.” Foreign Affairs 93, no. 2 (March 2014): 68-79. Academic Search Premier, EBSCOhost (accessed February 26, 2014). 
that the United States needs to restrain from drone proliferation, create an independent review panel to increase transparency, and that Congress needs to hold hearings to discuss the use of drones and the legal framework that allows it. ${ }^{27}$

Other scholars who seriously critique the UAV program as a whole contrast the above point of view. Instead of offering changes for the future of U.S. drone policy, they focus on the seriousness of the flaws of the program. Michael Boyle, writing for International Affairs, explains the theory of blowback; Boyle is arguing that the positive outcomes of the drone program — killing terroristshave not been accurately weighed against the negative outcomes. ${ }^{28}$ To explain further, Boyle only looks at the CIA-run drone campaigns outside theatres of war, and contends that the drone campaigns in Yemen, Somalia, and Pakistan undermine the efficacy of local governments and open the door for extremist Islamic groups to gain recruits. ${ }^{29} \mathrm{He}$ comes to the conclusion that the picture of the effectiveness of drones is not entirely what it may seem and follows up that notion with his possible solution; limiting drone strikes to high value targets (HVTs) only. ${ }^{30}$

Agreeing with Boyle's ideological stance on drones, Cronin authored a piece entitled "Why Drone's Fail," and argues against the effectiveness of the drone campaign as a whole. She begins with the idea that al Qaeda bears little to no resemblance to the other terrorist groups that have been successfully "destroyed through decapitation," or by the targeted killings of drone strikes. ${ }^{31}$ The disparity lies in the fact that the successfully destroyed groups were characterized by a cult of personality, hierarchical structure, and were no more than ten years old. Al Qaeda is a group that is about twenty-five years old and has a vast interconnected group of militants at its disposal. Cronin is disputing the efficacy of using drones as a counterterrorism tool to combat Al Qaeda. However, she does not dispute the high levels of destruction that have afflicted al Qaeda. She states that even while the group may be more concerned with staying alive versus planning attacks on the homeland, al Qaeda still has the

${ }^{27}$ Ibid

${ }^{28}$ BOYLE, MICHAEL J. “The costs and consequences of drone warfare." International Affairs 89, no. 1 (January 2013): 1-29. Academic Search Premier, EBSCOhost (accessed March 1, 2014)

${ }^{29}$ Ibid

${ }^{30}$ Op. cit. fn. 4

${ }^{31}$ Cronin, Audrey Kurth. "Why Drones Fail." Foreign Affairs 92, no. 4 (July 2013): 44-54. Academic Search Premier, EBSCOhost (accessed March 10, 2014). 
ability to "perpetuate its message." 32 Even if the militaristic wings of al Qaeda are unfocused and unsuccessful, the public relations campaign the organization is waging is keeping them afloat, hindering the United States' long-term goal of demobilizing the group. While Cronin does not doubt the full efficacy of the U.S. drone program like Boyle does, she argues that the destruction of Al Qaeda will not come solely from UAVs.

On the contrary, Byman in his piece "Why Drones Work," focuses on the necessity of drones as a tool in the United States' counterterrorism toolbox, contrasting Cronin's piece. He argues for targeting higher value terrorists along with the foot soldiers. ${ }^{33}$ "It has become more politically palatable for the United States to kill rather than detain suspected terrorists," Byman suggests. He counters the arguments most commonly given by the critics of drones; the alternatives to drones (i.e. raids) are unreasonable, how difficult it is to counter terrorism with political or financial means (i.e. bringing nations out of poverty), and that nonproliferation is essentially futile. ${ }^{34}$ Byman does address the fact that drone strikes may be unpopular according to a poll taken in Pakistan in 2012, but again highlights the lack of better alternatives; "74 percent of Pakistanis viewed the United States as their enemy, likely in part because of the ongoing drone campaign.... It is hard to imagine that alternatives to drone strikes, such as SEAL team raids or cruise missile strikes, would make the United States more popular."

Cronin and Byman make convincing arguments in their respective pieces, and they both touch upon an important piece to the puzzle when it comes to drone policies, the legal basis for UAV strikes. Much of the legal framework for counterterrorism measures taken since 2001 comes from the Authorization for the Use of Military Force (AUMF). Cronin does concede that the authorization from Congress was most likely a necessity during that time, but she disagrees with what the authorization has morphed into. The ambiguous phrasing of the legislation may have been originally intentional, but currently, "In this endless contest, the United States risks multiplying its enemies and heightening their incentives to attack the country." ${ }^{35}$ Byman does not completely agree with that

\footnotetext{
${ }^{32}$ Ibid

${ }^{33}$ Byman, Daniel. "Why Drones Work." Foreign Affairs 92, no. 4 (July 2013): 32-43. Academic Search Premier, EBSCOhost (accessed March 17, 2014).

${ }^{34}$ Ibid

35 Op. cit. fn. 7
} 
conclusion, but he does address the fact that the AUMF is twelve-plus years old, and it may not sufficiently cover the UAV program in its entirety.

\section{Research Findings}

Because much of the United States UAV program is shrouded in secrecy for national security reasons, it is difficult to decipher what are the concrete policies of the U.S. President Barack Obama, State Department Legal Advisor Harold Koh, and Central Intelligence Agency Director John Brennan have all given speeches on the topic, which are continually referenced by government officials when drone policy questions are asked. Each set of remarks, President Obama's, Koh's, and Brennan's, try to showcase the reasoning behind U.S. targeted killings by the way of drones. The AUMF was cited as being the legal basis for the actions taken. Other measures such as the increased transparency, though seemingly hollow, were outlined as well. In President Obama's speech at National Defense University, he references written counterterrorism policy standards entitled, "Presidential Policy Guidance," which outline the exact standards for the use of lethal force. ${ }^{36}$ Essentially, the policy standards reiterate what the White House and government agencies have been explaining to the American people. Lethal force is not an alternative for prosecution; it ideally is used only when there is a "continuing imminent threat to U.S. persons." The appropriate members of Congress have continuously been informed, the Department of Justice has been consulted to run legal analysis, but yet the President still maintains his authority to take action as he sees fit in a lawful manner, a reminder of the powerful legal authority the executive branch holds.

Harold Koh, the State Department Legal Advisor, took a different approach in his speech at the American Society of International Law. Koh outlined what was dubbed an "Emerging 'Obama-Clinton Doctrine'," which is comprised of four different areas to which the U.S. is committed..$^{38}$ The four areas correspond to the ideas that have been consistently iterated by the Obama administration, “...challenges of the twenty-first century can't be met by any one leader or any

\footnotetext{
36 "Fact Sheet: U.S. Policy Standards and Procedures for the Use of Force in Counterterrorism Operations Outside the United States and Areas of Active Hostilities," Press Secretary, The White House. May 23, 2013.

${ }^{37}$ Ibid

${ }^{38}$ Koh, Harold, "Legal Adviser Koh's Speech on the Obama Administration and International Law, March 2010,” Council on Foreign Relations. March 25, 2010.
} 
one nation," simply saying that the international community needs to become more interdependent. ${ }^{39}$ These elements frame the United States as the multilateral actor that former Secretary of State Clinton and President Obama may want the nation to be. Koh states, "U.S. targeting practices, including lethal operations conducted with the use of unmanned aerial vehicles, comply with all applicable law, including the laws of war." It is the AUMF that authorizes the U.S. to use force from a domestic standpoint. There are different international laws in place regarding the usage of force or more specifically targeted killings, however they disagree with the U.S.'s position and actions, so the federal government defers to domestic law. Koh's remarks seemed to be aimed towards satisfying the public and possibly other U.S. representative's calls for justification of the executive branch's actions. The phrasing " comply with all applicable law" aims to increase the legitimacy of Koh's claims and attempts to decrease the legitimacy of the criticisms of the drone program. Further, it sets the precedent that the only legal framework that matters is the U.S.'s, not international law.

At Harvard Law, John Brennan takes a more hawkish position stating, “... As President Obama has stated on numerous occasions, we reserve the right to take unilateral action if or when other governments are unwilling or unable to take the necessary actions themselves." Continuing, Brennan almost walks back that previous statement by pointing out that the U.S. cannot just use military force whenever it pleases, because the U.S. respects international law and state sovereignty. ${ }^{40}$ Brennan tries to shed light on the perspectives of intelligence agencies and the military by explaining that the face of warfare is changing, underscoring the necessity of drones. The U.S. military does not face the same type of combatant as they once did; al Qaeda wears no uniform and does not carry weapons openly. Brennan takes a similar path as Koh by offering what seem to be justifications for U.S. missteps; he argues that President Obama has actually increased transparency by allowing the release of budgetary information, reconstituting the Intelligence Oversight Board, and declassifying legal memos. ${ }^{41}$

${ }^{39}$ Ibid

${ }^{40}$ Wittes, Benjamin. “John Brennan's Remarks at HLS-Brookings Conference,” Lawfare: Hard National Security Choices, September 16, 2011.

${ }^{41}$ Ibid 
These remarks made by high-level officials are more or less the public version of the United States current UAV policy. Critics and skeptics are in no way satisfied with these claims and arguments because many of what are arguably the biggest questions surrounding the policies are unanswered. This has led to an outpouring of critiques regarding the current status of the program, how the U.S. should handle the program in the future, and assessments regarding the morality of the program as a whole.

Essentially, there are groups within the U.S. and throughout the international community that would like to see some hard data, some specifics, on the United States UAV program. There have been conflicting reports throughout news outlets on numbers of civilian causalities and the locations of U.S. drone strikes. Some specifics can be found; since 2008, the U.S. has administered 1,000 plus drone strikes in Afghanistan. As of July 2013, the British had conducted 299 drone strikes in Afghanistan comparatively. From 2008 onward, the U.S. has launched 48 drone strikes in Iraq, approximately 145 in Libya, 400 in Pakistan, 100 plus in Yemen, under 20 in Somalia, and possibly one in the Philippines. ${ }^{42}$

Conclusions can be drawn when hard data is analyzed. While Cronin argues against the use of drones, she does cede the point that, "Political scientists Patrick Johnston and Anoop Sarbahi recently found that drone strikes in northwestern Pakistan from 2007 to 2011 resulted in a decrease in the number and lethality of militant attacks in the tribal areas where they were conducted." ${ }^{43}$ There is definitely effectiveness to the weaponry; otherwise it would not be used on such a widespread scale. The effectiveness is only questioned insofar as the actual toll of civilian loss of life, and whether or not that leads to negative long-term effects, i.e. blowback. Cronin and Boyle, for example, both argue that the lasting impact drones have are adverse to the goals the administration is trying to achieve. The drones-first counterterrorism policy can be used as a recruiting tool for extremist organizations, undermine the stability and confidence of local governments, and increase anti-American sentiment. All of these implications have a high probability of being accurate. The "Times Square bomber" explained that his motives were directly related to drone strikes. More recently, the relationship between the United States and Pakistan has

42 Op. cit. fn. 2

${ }^{43}$ Op. cit. fn. 7 
been strained because the Pakistani government is facing hostile opposition to U.S. drone strikes. While the Pakistani government has often condemned the strikes in public, it is now widely known that they give the U.S. permission in private. In November 2013 there were protests in Peshawar, activists claim that the U.S. is hindering Pakistan's peace process with the Pakistani Taliban, as they were just about to begin negotiations when a drone strike killed a top Taliban leader. ${ }^{44}$

Drone strikes conducted on the Pakistani Taliban seem a long way from the policies described in the Authorization for the Use of Military Force. While the ambiguousness of the authorization is partly necessary to avoid obstacles regarding terrorist organizations changing their names to avoid sanctions, Cronin explains, "Washington now finds itself in a permanent battle with an amorphous and geographically dispersed foe, one with an increasingly marginal connection to the original 9/11 plotters. In this endless contest, the United States risks multiplying its enemies and heightening their incentives to attack the country." Daniel Byman in his article contradicting Cronin's piece does agree that Washington needs to improve drone policy to an extent. Speaking in regards to the targeting of Anwar Awlaki, the U.S. citizen that was targeted in Yemen, Byman states, "Yet with the war on terrorism almost 12 years old and bin Laden dead, critics, such as the Georgetown University law professor Rosa Brooks, have begun questioning whether the AUMF still justifies drone strikes today. As Brooks has argued, 'Many of the groups now being identified as threats don't fall clearly under the AUMF'S umbrella -- and many don't pose a significant danger to the United States.'”

The decision-making when it comes to deciding on drone strikes has been compared to a hostage situation, where police are not barred by the law from killing a hostage taker if they have a clear shot. Obviously there are some major differences between the urgency of a hostage situation at home and terrorists plotting miles away, but Mr. Leiter, former head of the National Counterterrorism Center, vocalizes that "[the president's reliance on strikes] is far from a lurid fascination with covert action and special forces. It's much

${ }^{44}$ Masood, Salman. Tipu Mehsud, Ihsanullah. "Thousands in Pakistan Protest American Drone Strikes," The New York Times. November 23, 2013. 
more practical. He's the president. He faces a post-Abdulmutallab situation, where he's being told people might attack the United States tomorrow." ${ }^{35}$

On top of the immediate policy implications are concerns of a drones arms race. The number of states with any type of drones has almost doubled since 2004, according to the U.S. Government Accountability Office. It is predicted that the civilian and military drone market will reach $\$ 8.4$ billion by 2018 , which will actually only be a portion of global defense spending which is supposed to hit $\$ 1.9$ trillion by the end of $2017 .{ }^{46}$ While the conjecture of a drone arms race may be farfetched, the advancements made in drone technology will make it easier to enter far away conflicts. Previously, when heads of state contemplated military action, they had to consider boots on the ground and the impact that would have. Now and in the future they will have the option to send an UAV to complete the obligations troops normally fulfill.

\section{Conclusion}

The Authorization for the Use of Military Force is a decade-plus old piece of legislation that had dictated the legal framework for the United States' counterterrorism policy following September 11, 2001. Developing throughout the Bush Administration and continuing in the Obama Administration, the use of UAVs as the main tool for countering terrorists abroad has been a direct implication of the AUMF. The ambiguous wording of the document has allowed President Obama to essentially create his own criteria for enacting these strikes, concentrating power within the Executive Branch. The costs and benefits of drone strikes are more easily understood than the legal framework that justifies them. The use of UAVs has had obvious positive outcomes when imminent threats are neutralized without having to place troops directly in harm's way. Because the program is relatively new, the long-term implications are difficult to decipher. As mentioned previously, there have been theories regarding possible blowback, with drone strikes negatively affecting the U.S.'s goals. Also, the proliferation of drone technology has yet to be seen on a grand scale, such as an arms race; however, it is a possibility that the technology could

${ }^{45}$ Becker, Joe. Shane, Scott. "Secret 'Kill List' Proves a Test of Obama’s Principles and Will," New York Times, May 29, 2012.

${ }^{46}$ Op. cit. fn. 2 
disseminate quickly, leaving questions about international policy regarding the use of drones.

Foundationally, there is little concrete information on the exact formula used by President Obama and his advisors when deciding on targets and when and where to strike. Further, the lack of foresight on the issue creates a vacuum and feeds speculation on future occurrences. Clearly there are national security concerns at stake, so full transparency is not an option. However, the United States needs to begin setting international precedent with the point in mind that other nations will garner this technology eventually. Essentially, the Obama administration needs to begin to look at the future of the UAV program instead of as a short-term solution to the problem of terrorism. 


\section{BIBLIOGRAPHY}

Becker, Joe. Shane, Scott. "Secret 'Kill List' Proves a Test of Obama's Principles and Will," New York Times, May 29, 2012. http://www.nytimes.com/2012/05/29/world/ obamas-leadership-in-war-on-al-qaeda.html?pagewanted=all\&_r=0'

BOYLE, MICHAEL J. “The costs and consequences of drone warfare.” International Affairs 89, no. 1 (January 2013): 1-29. Academic Search Premier, EBSCOhost (accessed March 1, 2014)

Byman, Daniel. "Why Drones Work." Foreign Affairs 92, no. 4 (July 2013): 32-43. Academic Search Premier, EBSCOhost (accessed March 17, 2014).

Cronin, Audrey Kurth. "Why Drones Fail.” Foreign Affairs 92, no. 4 (July 2013): 44-54. Academic Search Premier, EBSCOhost (accessed March 10, 2014).

"Fact Sheet: U.S. Policy Standards and Procedures for the Use of Force in Counterterrorism Operations Outside the United States and Areas of Active Hostilities," Press Secretary, The White House. May 23, 2013. http://www.whitehouse.gov/sites/ default/files/uploads/2013.05.23_fact_sheet_on_ppg.pdf

Koh, Harold, "Legal Adviser Koh's Speech on the Obama Administration and International Law, March 2010," Council on Foreign Relations. March 25, 2010.

Kreps, Sarah, and Micah Zenko. "The Next Drone Wars." Foreign Affairs 93, no. 2 (March 2014): 68-79. Academic Search Premier, EBSCOhost (accessed February 26, 2014).

Masood, Salman. Tipu Mehsud, Ihsanullah. "Thousands in Pakistan Protest American Drone Strikes," The New York Times. November 23, 2013.

S.J.Res. 23 (107th): Authorization for Use of Military Force. 107th Congress, 2001-2002. Text

Wittes, Benjamin. “John Brennan's Remarks at HLS-Brookings Conference," Lawfare: Hard National Security Choices, September 16, 2011. http://www.lawfareblog. com/2011/09/john-brennans-remarks-at-hls-brookings-conference/\#. UuxalndmWXR 